\title{
Erythropoietin Production by Fetal Mouse Liver Cells in Response to Hypoxia and Adenylate Cyclase Stimulation*
}

\author{
ARMIN KURTZ, WOLFGANG JELKMANN, ANDREAS PFUHL, \\ KERSTIN MALMSTRÖM, AND CHRISTIAN BAUER \\ Physiologisches Institut der Universität Zürich (A.K., K.M., C.B.), CH-8057 Zürich, Switzerland; \\ Physiologisches Institut der Medizinischen Hochschule Lübeck (W.J.), D-2400 Lübeck, West Germany; and \\ Institut für Physiologie der Universität Regensburg (A.P.), D-8400 Regensburg, West Germany
}

\begin{abstract}
This study was done to investigate aspects of control of extrarenal erythropoietin (Ep) production. To this end we studied the effects of three stimuli of renal Ep production in the adult, i.e. hypoxia, cobalt, and activation of adenylate cyclase on Ep generation by cultured fetal mouse liver cells. The fetal liver was taken as a model for extrarenal Ep production because this organ is considered the predominant site of extrarenal Ep production. We found that Ep production by the cells increased as the oxygen concentration was decreased in the incubation atmosphere from $20 \%$ to $1 \%$. Cobalt $\left(10^{-4}-10^{-5} \mathrm{M}\right)$
\end{abstract}

had no effect on Ep production. Activation of adenylate cyclase by forskolin $\left(10^{-5} \mathrm{M}\right)$ or isoproterenol $\left(10^{-5} \mathrm{M}\right)$ greatly enhanced Ep production. These findings indicate that the Ep-stimulating effect of cobalt is specific for the kidney. However, oxygen depletion and activation of adenylate cyclase seem to be more general stimuli in Ep-producing cells. Furthermore we found that Ep production in hypoxia correlated with lactate formation in the cultured liver cells. This finding suggests that Ep production in fetal livers under hypoxic conditions parallels the shift from aerobic to anaerobic cellular energy metabolism. (Endocrinology 118: 567-572, 1986)
$\mathrm{E}$ RYTHROPOIETIN (Ep) is a growth factor known to stimulate erythropoiesis. Ep has been demonstrated in a variety of tissues including kidney (1), liver (2), submandibulary glands (3), and macrophages (4). Although the existence of Ep in an organ does not imply production by the organ the liver is considered as the primary site of Ep production during fetal life $(5,6)$. After birth Ep production shifts to the kidney $(7,8)$, and in the adult extrarenal Ep production accounts for less than $15 \%$ of the total (9). There is considerable information regarding the control of Ep production by the adult kidney. In contrast, information regarding the regulation of extrarenal Ep production is limited, and it is not clear whether extrarenal Ep production is activated by the same stimuli as renal Ep production. Recently, Zucali and Mirand (10) reported in a series of investigations that cultures of fetal mouse liver cells are capable of producing $\mathrm{Ep}$, and we have shown that renal cell cultures are suitable for study of the mechanisms of Ep production in the kidney (11). Thus, in the present

Received August 30, 1985

Address correspondence and requests for reprints to: Dr. Armin Kurtz, Physiologisches Institut der Universität Zürich Irchel, Winterthurerstrasse 190, CH8057 Zürich, Switzerland.

* This work was partly supported by Grant NF 3.023-0.84 from the Swiss National Science Foundation. studies, we employed cultures of fetal mouse livers to investigate the effects of hypoxia, cobalt, and activation of the adenylate cyclase by isoproterenol and forskolin on hepatic Ep production. We found that hypoxia and activation of the adenylate cyclase enhanced Ep formation whereas cobalt had no effect. Furthermore, we obtained evidence that Ep production stimulated by hypoxia tends to parallel the increase in lactate production which marks the shift of cellular energy metabolism from aerobic to anaerobic pathways.

\section{Materials and Methods}

\section{Cell cultures of fetal mouse livers}

Fetal mouse liver cell cultures were established basically as described by Zucali and Mirand (12). In brief, fetál livers were obtained from NMRI-strain mice (Dr. Ivanovas, Kisslegg, West Germany) at the 13 th to 14 th day of gestation. Livers were aseptically removed from the fetuses and subsequently disag. gregated in a single cell suspension by vigorous pipetting with a Pasteur pipette. Cell debris was removed by washing the cell suspension twice with culture medium (RPMI 1640, $100 \mathrm{U} / \mathrm{ml}$ penicillin, $100 \mu \mathrm{g} / \mathrm{ml}$ streptomycin, $10 \%$ fetal bovine serum; all agents were from Boehringer, Mannheim, West Germany). Cells were seeded at a density of $1 \times 10^{6}$ nucleated cells $/ \mathrm{cm}^{2}$ into $75 \mathrm{~cm}^{2}$ culture flasks (Greiner, West Germany) containing $10 \mathrm{ml}$ culture medium. Cells were cultivated in incubators 
maintaining a humidified gas atmosphere 1:4:15 of carbon dioxide-oxygen-nitrogen at $37 \mathrm{C}$, respectively. The first renewal of the culture medium was done 1 day after seeding of the cells. Most nonadherent cells were removed by this procedure. The next refeeding of the cells was done 3 days later (day 4 of culture).

\section{Studies on the Ep production rate}

Ep production rate studies of the cultures were done between the fourth and seventh day of culture, using a culture medium that contained $5 \%$ instead of $10 \%$ fetal bovine serum. For determination of the effect of oxygen tension on the Ep production rate, cultures were kept at either $20 \%, 10 \%, 5 \%, 2 \%$, or $1 \%$ oxygen for 3 days between the fourth and seventh day of culture using $\mathrm{O}_{2}$ controlled incubators (Heraeus, Hanau, West Germany). The effects of cobalt, forskolin, and isoproterenol on Ep production were examined by adding aliquots of freshly prepared stock solutions of cobaltous chloride $\left(10^{-2} \mathrm{M}\right)$, forskolin $\left(10^{-2} \mathrm{M}\right)$, and isoproterenol $\left(10^{-3} \mathrm{M}\right)$ to the cultures for 3 days and at $5 \%$ oxygen. $\mathrm{pO}_{2}$ was determined in the gas atmosphere in the incubator using a $\mathrm{pO}_{2}$ electrode.

\section{Ep activity}

Ep activity in the culture medium was assayed with the posthypoxic polycythemic mice assay for Ep exactly as described (13). In brief, NMRI-strain female mice $(25 \mathrm{~g})$ were made polycythemic by exposure to 0.42 atmosphere for $20 \mathrm{~h} /$ day for 2 weeks. On the sixth and seventh posthypoxic days, five to six mice per sample were injected sc with standard doses of human urinary Ep (calibrated against the International Standard Preparation B) or with the unknown samples. On the eighth day, each mouse received $0.5 \mu \mathrm{Ci}{ }^{59} \mathrm{Fe}$-citrate (Amersham Buchler, Braunschweig, West Germany). Forty-eight hours later, the mice were bled by heart puncture and the percentage of radioiron incorporation into the blood was determined. Ep titers in the unknowns were calculated from log dose-log response curves of the Ep standards. Figure 1 shows an averaged dose response curve of seven different assays.

If not otherwise indicated, culture media from 3-day incubations were assayed. Heretofore the supernatants of 30 (75 $\left.\mathrm{cm}^{2}\right)$ flasks $(300 \mathrm{ml})$ were pooled and concentrated 60 -fold by ultrafiltration on Amicon YM-10 membranes. Each assay mouse received $2 \times 0.5 \mathrm{ml} 60$-fold concentrated medium. Ep activities of culture media shown in Results were corrected for the Ep activity of pure culture medium which was determined in each assay as a control. Sixty-fold concentrated control medium caused an iron incorporation of $1.02 \pm 0.12 \%$ in five different assays. From the double-logarithmic plotting of the dose response curve for human standard Ep (Fig. 1) the mean Ep activity of 60 -fold concentrated control medium was calculated as $15 \mathrm{mU} / \mathrm{ml}$.

\section{Lactate concentrations}

Lactate concentrations in the culture media were determined with a commercial kit for L-lactate (Boehringer).

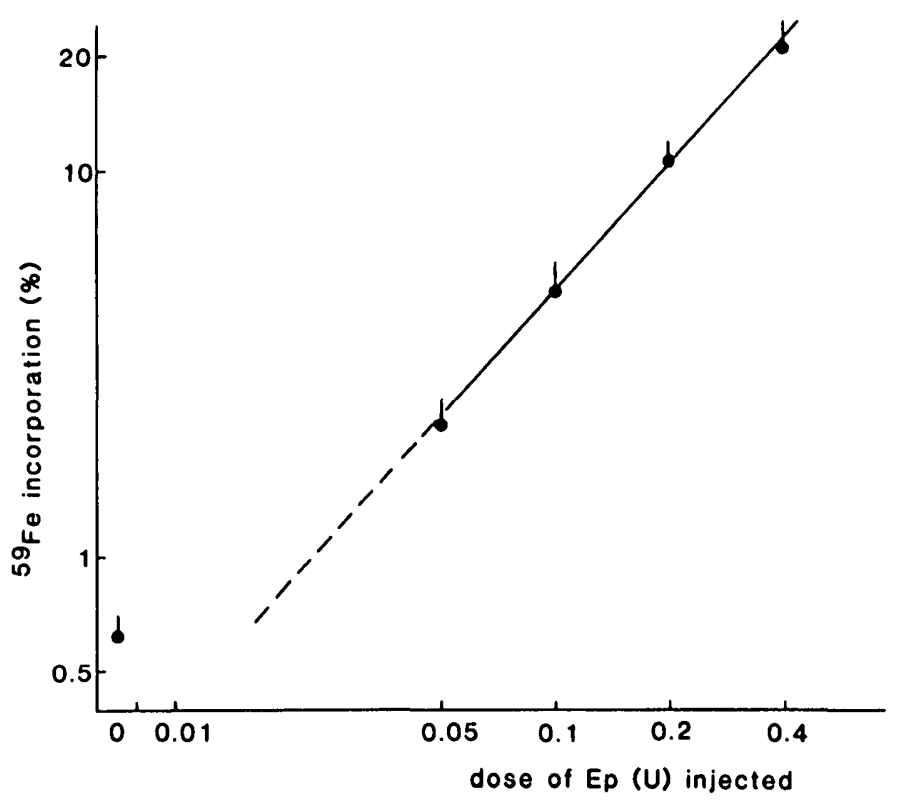

FIG. 1. Dose reponse curve for human standard Ep on ${ }^{69} \mathrm{Fe}$ incorporation into the assay mice. Data are mean $\pm S E M$ of seven different assays.

\section{Determination of intracellular cAMP levels}

To determine intracellular cAMP levels, the culture medium was substituted by prewarmed L-15 medium (Boehringer) with or without forskolin $\left(10^{-5} \mathrm{M}\right)$ or isoproterenol $\left(10^{-5} \mathrm{M}\right)$, and the culture dishes $\left(7 \mathrm{~cm}^{2}\right)$ were placed on a heater maintaining a temperature of $37 \mathrm{C}$. Five minutes after addition the L-15 medium was withdrawn and the dishes were placed on an ice block. After addition of $0.4 \mathrm{ml}$ ice-cold buffer (containing $5 \mathrm{mM}$ potassium phosphate, $0.2 \mathrm{~mm}$ EDTA, $0.5 \mathrm{~mm} 3$-isobutyl-methylxanthine, and $150 \mathrm{mM} \mathrm{KCl}, \mathrm{pH} 6.8$ ) the cells were scraped off with a teflon policeman. The obtained suspension was sonicated, boiled for $5 \mathrm{~min}$, and centrifugated. The supernatants were assayed for cAMP using a cAMP binding assay for cAMP exactly as described (14).

\section{Isoproterenol concentrations}

Isoproterenol concentrations in the samples assayed for Ep in the polycythemic mice were determined by HPLC. Protein was precipitated by addition of perchloric acid (final concentration, $0.1 \mathrm{M}$ ) to each sample. After centrifugation, aliquots of the supernatants were analyzed on a prepacked column (Hyperchrome C 18, $5 \mu \mathrm{m}$, Bischoff, Düren, West Germany). The solvent system for the isocratic elution was buffer-methanol = 93:7 (buffer: L-octylsulfonic acid, sodium salt, $12 \mathrm{mg} /$ liter; citric acid-monohydrate, $8 \mathrm{~g} /$ liter; $\mathrm{Na}_{2}$ EDTA, $50 \mathrm{mg} /$ liter; $\mathrm{pH} 4.0$ in water). The column was calibrated with isoproterenol dissolved in $0.1 \mathrm{M}$ perchloric acid.

\section{Results}

Effect of hypoxia on Ep formation of cultured fetal livers

Figure 2a shows the Ep production rate of the cultured livers at different oxygen tensions in the incubation 
Fic. 2. a, Oxygen dependence of Epp production by cultured fetal mouse livers. Data are given as mean \pm SEM. Experiments at 6,12 , and 60 torr were done three times each; those at 30 and 120 torr five times each. The dashed line is the regression curve $(y=156 / x+4.2 ; r$ $=0.97)$. $\mathrm{b}$, Oxygen dependence of lactate formation by cultured fetal mouse livers. Data are given as mean \pm SEM of 10 experiments. The dashed line represents the regression curve $(y=5424 / x+72 ; r$ $=0.94$ ).
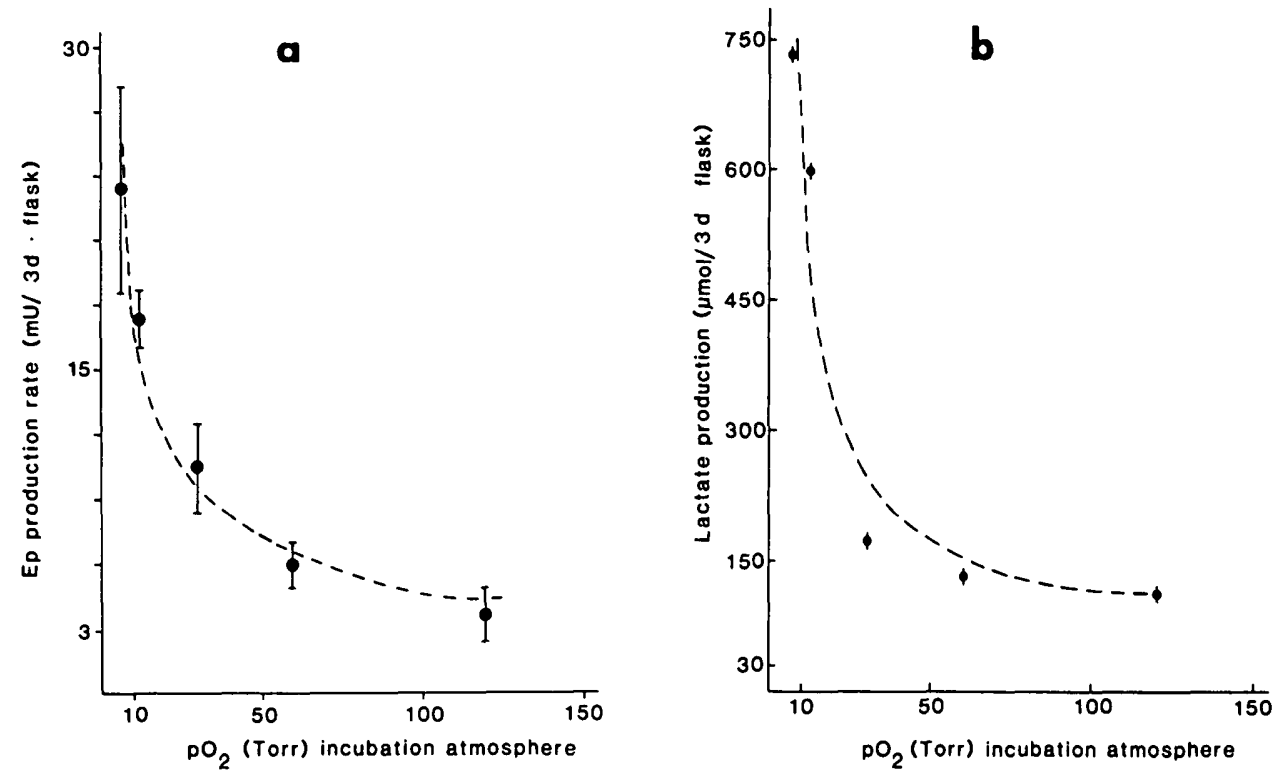

atmosphere. It is evident that the Ep production rate increased as the $\mathrm{pO}_{2}$ decreased in the incubation atmosphere from 120 to 7 torr. The Ep production rate at 7 torr was about 6 -fold higher than that at 120 torr. The oxygen dependent Ep production rate (y) can be described as an inverse function of the $\mathrm{pO}_{2}(x)$ as follows: $(\mathrm{y}=156 / \mathrm{x}+4.2 ; \mathrm{r}=0.97)$.

Figure $2 b$ shows the lactate formation rate of the cultured livers at different oxygen tensions. It is obvious that lactate production by the cultures also increased with decreasing $\mathrm{pO}_{2}$. The oxygen dependence of lactate formation (y) also can be described by the inverse function of $\mathrm{pO}_{2}(\mathrm{y}=5424 / \mathrm{x}+72 ; \mathrm{r}=0.94)$.

The effect of cobaltous chloride $\left(10^{-4} \mathrm{M}\right.$ and $\left.10^{-5} \mathrm{M}\right)$ on Ep formation at $20 \%$ and $5 \%$ oxygen was examined three times, but in no case could a stimulation of Ep formation by cobalt be observed.

\section{Effect of adenylate cyclase stimulation on Ep formation} by cultured fetal livers

Isoproterenol and forskolin are well documented stimulators of adenylate cyclase (15). To ensure that these agents also stimulate adenylate cyclase of cultured fetal livers cells, we determined intracellular cAMP levels at 5 and $30 \mathrm{~min}$ after addition of isoproterenol and forskolin to the cells. Table 1 shows that both isoproterenol $\left(10^{-5}\right.$ $\mathrm{M})$ and forskolin $\left(10^{-5} \mathrm{M}\right)$ caused significant increases in intracellular cAMP levels. The effects of these agents on Ep production by the cultures are shown in Fig. 3a. Both agents enhanced Ep production by a factor of 7-8. As a control we determined the effect of culture medium that had been incubated with isoproterenol $\left(10^{-5} \mathrm{M}\right)$ or forskolin $\left(10^{-5} \mathrm{M}\right)$ for 3 days. These controls failed to stimulate iron incorporation into the assay mice. Since
TABLE 1. Intracellular cAMP levels after addition of isoproterenol $\left(10^{-5} \mathrm{M}\right)$ and forskolin $\left(10^{-5} \mathrm{M}\right)$

\begin{tabular}{lccr}
\hline & \multicolumn{3}{c}{ cAMP (pmol/dish) } \\
\cline { 2 - 4 } & 0 & $5 \mathrm{~min}$ & \multicolumn{1}{c}{$30 \mathrm{~min}$} \\
\hline Control & $3.08 \pm 0.35$ & $3.28 \pm 0.20$ & $2.95 \pm 0.31$ \\
Isoproterenol & $3.08 \pm 0.35$ & $6.46 \pm 0.03$ & $24.37 \pm 0.95$ \\
Forskolin & $3.08 \pm 0.35$ & $33.78 \pm 10.79$ & $35.13 \pm 3.97$ \\
\hline
\end{tabular}

Data are mean \pm SEM of five experiments.

high concentrations of isoproterenol are known to enhance iron incorporation in mice (16), we determined the isoproterenol concentrations in the medium samples by HPLC. It turned out that the concentration of isoproterenol was lowered from $10^{-5}-10^{-7} \mathrm{M}$ after a 3-day incubation period.

Figure $3 \mathrm{~b}$ shows the lactate formation of the cultured livers in the presence of isoproterenol or forskolin. It is evident that the production of lactate was not stimulated by isoproterenol or by forskolin.

\section{Discussion}

To determine whether the same stimuli of Ep production in the adult kidney also are active in the fetal liver, we investigated the effects of hypoxia, cobalt, and activation of adenylate cyclase on Ep production by cultivated fetal mouse liver cells. We found that the production of Ep by the cultured fetal livers was increased by lowering the oxygen tension in the incubation atmosphere. This finding is in agreement with the results of a study by Zucali (17) who reported a 2-fold increase in Ep production by fetal mouse liver cultures, when the oxygen concentration in the incubator was lowered from $19 \%$ to $13 \%$. Note that we found a more significant stimulation of Ep production at much lower oxygen concentrations 
Fig. 3. a, Ep production rate of cultured fetal mouse livers at $5 \% \mathrm{O}_{2}$ in presence and absence of isoproterenol $\left(10^{-5} \mathrm{M}\right)$ and forskolin $\left(10^{-5} \mathrm{M}\right)$. Data are mean \pm SEM. Figures at the bottom of the columns indicate number of experiments. b, Lactate formation rate of cultured fetal mouse livers at $5 \% \mathrm{O}_{2}$ in presence and absence of isoproterenol $\left(10^{-5} \mathrm{M}\right)$ and forskolin $\left(10^{-5} \mathrm{M}\right)$. Data are mean $\pm \mathrm{SEM}$. Figures at the bottom of the columns indicate number of experiments.

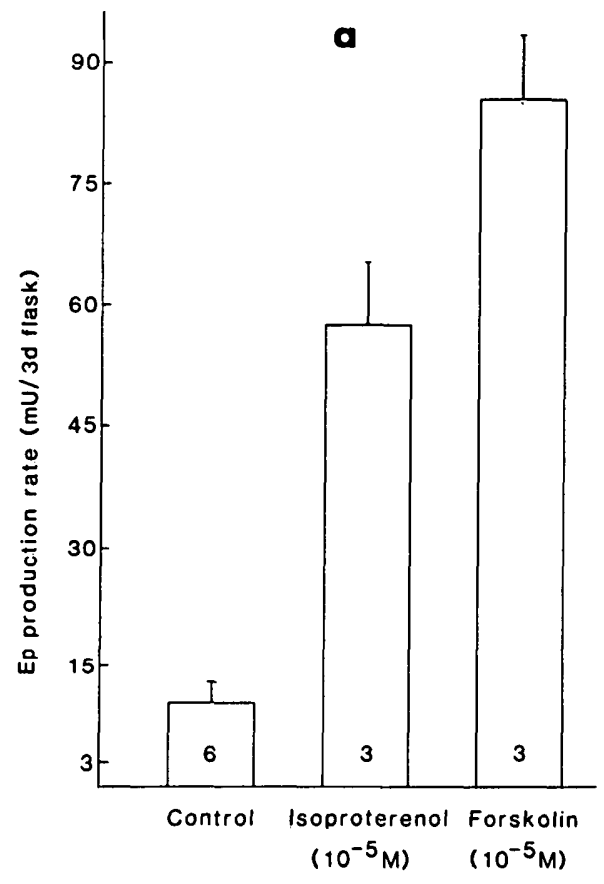

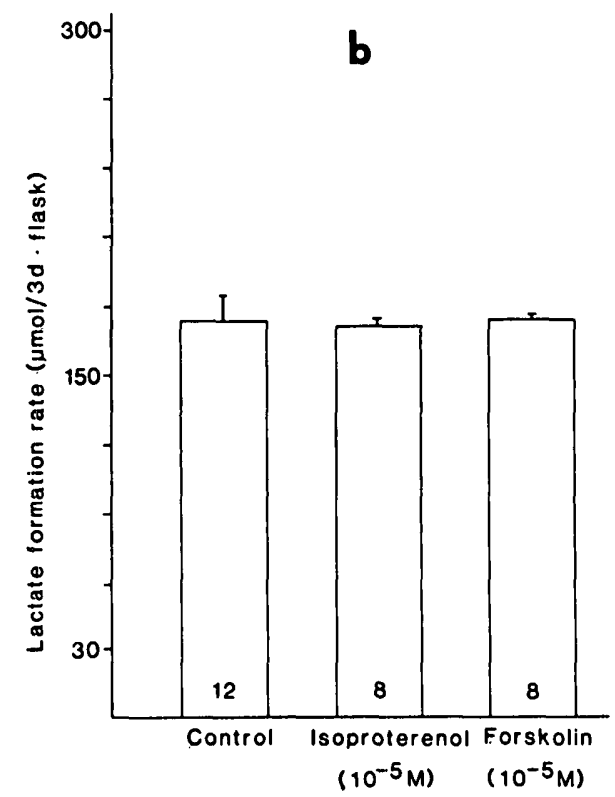

(Fig. 2a). Our results also are in agreement with earlier in vivo studies of Zanjani et al. (18) showing that the plasma Ep concentration in fetal blood is elevated during hypoxia. Philipps et al. (19) also found a dependence of plasma Ep concentrations on the oxygen content in the blood in in vivo experiments. It can be concluded, therefore, that the oxygen sensing mechanism which leads to an increased Ep production in fetal liver is not disturbed by cultivation of the cells. Our results furthermore show that the lactate production rate of the cultured liver had a very similar oxygen dependence as the Ep production rate (Fig. 2). If one accepts lactate production as an index for the shift of the cellular energy metabolism from the aerobic to the anaerobic pathway, one can conclude from this result that Ep production in the fetal liver tends to parallel the shift of the energy metabolism into the anaerobic pathway. Interestingly we found the same relationship between lactate and Ep production in cultures of renal mesangial cells (unpublished results). A comparison of the oxygen dependencies of Ep production in cultured fetal liver and cultured mesangial cells suggests that the oxygen sensors of both tissues have similar sensitivity under cell culture conditions (Fig. 4).

In contrast to its effect on the kidney, cobalt had no effect on Ep production by cultured liver cells. Since the mechanism by which cobalt enhances Ep production in the kidney is not well understood, we cannot conclude from our finding which specific pathway of stimulating Ep formation is lacking in the fetal liver.

Prostaglandins (20) and $\beta$-adrenergic agonists (16) are potent stimulators of renal Ep production. Since these agents are considered to act mainly by activating ade-

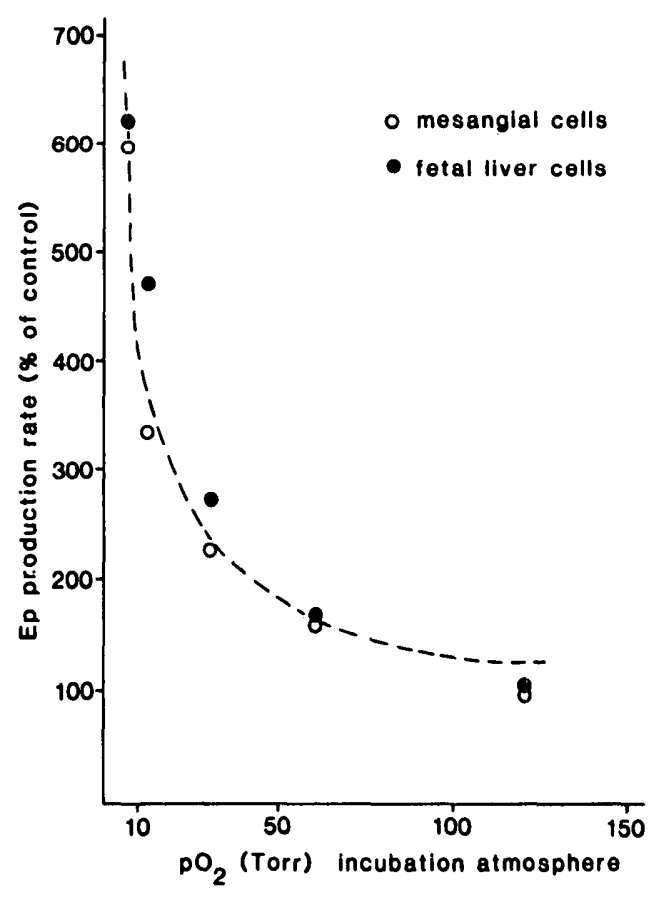

FIG. 4. Comparison of oxygen dependencies of Ep production rates between cultured renal mesangial cells and cultured fetal mouse liver cells. Ep production is given as percent of control. Ep production at a $\mathrm{pO}_{2}$ of 120 torr was taken as $100 \%$ of control. The data for mesangial cells have been taken from Ref. 11 and that for fetal livers from Fig. 1a. The dashed line is the regression curve $(y=4017 / x+96 ; r=0.97)$.

nylate cyclase (23), we investigated the effects of the adenylate cyclase activators isoproterenol and forskolin on Ep production in the cultured fetal livers cells. Both agents enhanced cAMP levels and Ep production by the cells. It might be argued that erythropoietic activity of these culture media could have resulted from the agents 
being carried over into the assay mice rather than by Ep itself; isoproterenol can indeed enhance radioiron incorporation in the mouse (16). However, control media containing isoproterenol or forskolin failed to stimulate iron incorporation. Furthermore we determined the isoproterenol concentrations in the samples by HPLC before assay of $\mathrm{Ep}$ and found that the samples contained less than $\left(10^{-7} \mathrm{M}\right)$ isoproterenol. We calculated that one assay mouse received less than $0.5 \mu \mathrm{g}$ isoproterenol/day and $\mathrm{kg}$ body weight. Thus a small dose of isoproterenol cannot account for the measured Ep activity of about $360 \mathrm{mU} / \mathrm{ml} \mathrm{(16).} \mathrm{The} \mathrm{lowered} \mathrm{concentration} \mathrm{of} \mathrm{isopro-}$ terenol after 3 days of culture is not unexpected in view of the short half-lifetime of isoproterenol in the presence of oxygen and nonacid $\mathrm{pH}$ values (22). Our results, therefore, further support the idea that activation of adenylate cyclase enhances Ep production in Ep-generating fetal liver cells. It is unlikely, also, that isoproterenol exerted its effect on Ep production by increasing the cellular oxygen consumption causing intracellular hypoxia (23). We found that isoproterenol did not stimulate lactate formation by the cultured livers.

The question arises whether the mechanism(s) by which hypoxia and activation of adenylate cyclase stimulate Ep synthesis are related. In cultures of mesangial cells we had obtained evidence that activation of adenylate cyclase mediates the effect of hypoxia on Ep formation (24). Adenylate cyclase in these cells probably was activated by prostaglandin $E_{2}$, for which an increased synthesis during hypoxia was found (24). Preliminary studies suggest that prostaglandins may be involved in the stimulation by hypoxia of Ep production in fetal liver cells. When the prostaglandin synthase inhibitor indomethacin $\left(10^{-5} \mathrm{M}\right)$ was added to cultured fetal livers, Ep formation was abolished even in presence of an incubator oxygen tension of 7 torr (unpublished observation). We reported a similar observation in cultured mesangial cells (24). It seems likely, therefore, that hypoxia stimulates Ep production in the kidney and in the fetal liver by enhancing the production of certain prostaglandins.

Finally we may consider the type of cell that could be responsible for the production of erythropoietin in liver cultures. Carbon particle ingestion studies $(25,26)$ and immunofluorescent studies $(8,27)$ have localized the site of hepatic Ep production to the Kupffer cells. More recently Paul et al. (27) clearly demonstrated that isolated rat Kupffer cells are capable of secreting Ep. Therefore, we determined the percentage of Kupffer cells in the present cultures, using their capability of phagocytosing latex beads. We found that primary cultures of fetal mouse liver cells regularly contained about $30 \%$ of latex phagocytosing cells between 4 and 7 days of culture. By a simple trypsination procedure we obtained subcultures containing about $90 \%$ Kupffer cells. The culture media of these cells were repeatedly assayed for Ep activity in the polycythemic mouse assay, and in no instance was significant Ep activity detected. The culture density of Kupffer cells in these subcultures, however, was only one-fifth of that of the primary cultures. Considering the rather high detection limit for $\mathrm{Ep}$ of the polycythemic mouse assay it was not clear whether fetal Kupffer cells in cultures were incapable of Ep production, or whether Ep activity in the culture media of the Kupffer cells was low because of the low cellular density. The results of the study by Paul et al. (28), clearly support the second explanation.

\section{Acknowledgments}

We are indebted to Dr. M. Fuchs for his help in the determination of isoproterenol concentrations by HPLC. The skillful technical assistance of R. Ludwig and I. Weissbrodt is gratefully acknowledged. We furthermore thank Mrs. Stoupa for her secretarial help and Mr. Gehret for doing the artwork.

\section{References}

1. Jacobson LO, Goldwasser E, Fried W, Plzak L 1957 Role of kidney in erythropoiesis. Nature 179:633

2. Fried W 1972 The liver as source of extrarenal erythropoietin production. Blood 40:671

3. Fava-de-Moraes F, Zangheri ED, Doine AJ 1979 Immunohistochemical localization of erythropoietin in the rat or mouse submandibular gland. Histochem J 11:97

4. Rich JN, Heit W, Kubanek B 1982 Extrarenal erythropoietin production by macrophages. Blood 60:1007

5. Peschle C, Mesone G, Genovese A, Magli C, Condorelli M 1976 Erythropoietin production in the rat: additive role of kidney and liver. Am J Physiol 230:845

6. Zanjani ED, Poster J, Burlington H, Mann LJ, Wasserman LR 1977 Liver as the primary site of erythropoietin production in the fetus. J Lab Clin Med 89:640

7. Lucarelli G, Dorcellini A, Carnevali C, Carmena A, Stohlmann F 1968 Fetal and neonatal erythropoiesis. Ann NY Acad Sci 149:544

8. Gruber DF, Zucali JR, Wlecklinski J, La Russa V, Mirand EA 1977 Temporal transition in the site of rat erythropoietin production. Exp Hematol 5:399

9. Ersley AJ, Caro J, Kansu E, Silver R 1980 Renal and extrarenal erythropoietin production in anaemic rats. $\mathrm{Br} \mathrm{J}$ Haematol 45:65

10. Zucali JR, Mirand EA 1978 In vitro aspects of erythropoietin production. In: Murphy M (ed), In Vitro Aspects of Erythropoiesis. Springer, New York, p 218

11. Kurtz A, Jelkmann W, Sinowatz F, Bauer C 1983 Renal mesangial cell cultures as a model for study of erythropoietin production. Proc Natl Acad Sci USA 80:4008

12. Zucali JR, Mirand EA 1976 A controlled environmental culture system for the production of erythropoietin. Scand J Haematol $16: 161$

13. Jelkmann W, Bauer C 1981 Demonstration of high levels of erythropoietin in rat kidneys following hypoxic hypoxia. Pflügers Arch 392:34

14. Brown BL, Ekins RP, Albano JDM 1972 Saturation assay for cyclic AMP using endogeneous binding protein. In: Greengard P, Robinson GA (eds) Advances in Cyclic Nucleotide Research. Raven Press, New York, vol 2:25

15. Seamon KB, Daly JW 1983 Forskolin, cyclic AMP and cellular physiology. Trends Pharmacol Sci 4:1

16. Fink GD, Fisher JW, 1977 Role of the sympathetic nervous system in the control of erythropoietin production. In: Fisher JW (ed) 
Kidney Hormones. Academic Press, London, vol. 2:387

17. Zucali JR 1980 Fetal liver cell conditioned media as a source of erythropoietic stimulating activities. Exp Hematol [Suppl. 8] 8:103

18. Zanjani ED, Peterson EN, Gordon AS, Wasserman LR 1974 Erythropoietin production in the fetus: role of the kidney and maternal anemia. J Lab Clin Med 83:281

19. Philipps AF, Widness JA, Garcia JF, Raye JR, Schwartz R 1982 Erythropoietin elevation in the chronically hyperglycemic fetal lamb. Proc Soc Exp Biol Med 170:42

20. Fisher JW 1980 Prostaglandins and kidney erythropoietin production. Nephron 25:53

21. George WJ, Rodgers GM 1977 Cyclic nucleotides and the regulation of erythropoiesis. In: Fisher JW (ed) Kidney Hormones. Academic Press, London, vol 2:329

22. von Euler US 1946 Presence of a substance with sympathin E properties in spleen extracts. Acta Physiol Scand 11:168
23. Marley E, Stephenson JD 1972 Central actions of catecholamines: oxygen consumption. In: Eichler O, Farah A, Herken H, Welch AD (eds) Handbook of Experimental Pharmacology. Springer, New York, $p 491$

24. Kurtz A, Jelkmann W, Pfeilschifter J, Bauer C 1985 Prostaglandins are involved in the hypoxia stimulated erythropoietin production in cultured renal mesangial cells. Am J Physiol 249(1):C3

25. Peschle C, Marone G, Genovese A, Rappaport JA, Condorelli M 1976 Increased erythropoietin production in anephric rats with hyperplasia of the reticuloendothelial system induced by colloidal carbon or zymosan. Blood 47:325

26. Gruber DF, Zucali JR, Mirand EA 1977 Identification of erythropoietin producing cells in fetal mouse liver cultures. Exp Hematol 5:392

27. Paul P, Rothmann SA, McMahon JR, Gordon AS 1984 Erythropoietin secretion by isolated rat Kupffer cells. Exp Hematol 12:825

\section{8th ESCPB Conference \\ Strasbourg, France \\ August 31-September 2, 1986}

Comparative Physiology of Environmental Adaptations (with 3 specialized symposiums):

1. Adaptations to salinity and dehydration

2. Adaptations to extreme environments

3. Adaptations to climatic changes.

For more information, please contact:

Prof. R. Kirsch

ESCPB Conference

Laboratoire de Zoologie

12 rue de l'Université

67000 Strasbourg

France 